\title{
A reporting guide for Surveys
}

Correspondence: ccdr-rmtc@phac-aspc.gc.ca

Suggested citation: A reporting guide for Surveys. Can Commun Dis Rep. 2017;43(9):184-5. https://doi.org/10.14745/ccdr.v43i09a04

Surveys are useful to describe "what is". They are used in health and public health research to learn about current opinions, knowledge and practice, to estimate the prevalence of a condition, to assess self-reported health status, to document risk-seeking and health-seeking behaviours and to gather preliminary information for future studies (1). Survey methods have changed from being paper-based to being largely electronic-mediated. Most surveys are now self-administered and completed online, by email, with apps or a combination of these (such as an email invitation with a link to an online questionnaire). A Cochrane review found that survey results from apps may have data equivalence to those obtained by more traditional methods when the setting, frequency and clinical application, in which the survey instrument was validated, remain the same (2).

Survey research is used for exploratory or descriptive research as it is relatively inexpensive, can cover a broad geographical area, includes thousands of people and allows for greater honesty when anonymity is assured. Surveys are not useful for causal research due to the risk of confounding bias (where an observed association between two variables is due to an association of both variables with an unmeasured third variable).

Usually surveys do not require a formal ethics review. Informed consent is still indicated, however, and can be met by identifying who is conducting the survey, the purpose, how long it will take to complete, any incentives and how personal information will be protected. For web-based surveys it is a best practice to calculate participation rate by measuring the number of unique visitors who filled out the first page of the survey, divided by the number of unique site visitors (3).

When reporting on survey research it is important to describe the objective, study population, development of the survey instrument and how the study was conducted, including the sampling strategy. The results need to include the response rate and the discussion needs to consider if and how the response rate, selection bias, positive response bias and threats to the reliability and validity of the survey questions may have influenced the results.

The Canada Communicable Disease Report (CCDR) has developed a 22-item checklist for reporting on surveys in the area of infectious diseases, which is based on the Checklist for Reporting Results of Internet E-Surveys (CHERRIES) (3), a previous checklist (4) as well as best practices in scientific communications (Table 1). A survey report is generally 1,500 to 2,000 words in length. As with all submissions, check CCDR's Information for Authors for general manuscript preparation and submission requirements (5).
Table 1: Checklist for reporting on surveys

\begin{tabular}{|c|c|c|}
\hline Reporting item & Item \# & Description \\
\hline \multicolumn{3}{|l|}{ Title/Abstract } \\
\hline Title & 1 & $\begin{array}{l}\text { Compose a title that identifies the } \\
\text { topic of the survey and the population } \\
\text { studied. }\end{array}$ \\
\hline Abstract & 2 & $\begin{array}{l}\text { Provide a } 250 \text {-word structured } \\
\text { abstract that includes the objective, } \\
\text { methodology (including study } \\
\text { setting, population and questionnaire } \\
\text { development and administration), } \\
\text { results (including the response rate and } \\
\text { key findings) and conclusion. }\end{array}$ \\
\hline \multicolumn{3}{|l|}{ Introduction } \\
\hline Issue identification & 3 & $\begin{array}{l}\text { Identify the topic of the study and why } \\
\text { it is important. }\end{array}$ \\
\hline Rationale for study & 4 & $\begin{array}{l}\text { Cite the relevant literature and identify } \\
\text { how this survey will add to what is } \\
\text { already known. }\end{array}$ \\
\hline $\begin{array}{l}\text { Objective and } \\
\text { rationale }\end{array}$ & 5 & $\begin{array}{l}\text { Clearly articulate the objective of the } \\
\text { study and explain why the survey was } \\
\text { the appropriate method to address it. }\end{array}$ \\
\hline \multicolumn{3}{|l|}{ Methods } \\
\hline $\begin{array}{l}\text { Population, time } \\
\text { and place }\end{array}$ & 6 & $\begin{array}{l}\text { Describe the setting and study } \\
\text { population for the survey, including the } \\
\text { dates it was undertaken. Note if it was } \\
\text { a convenience sample. }\end{array}$ \\
\hline $\begin{array}{l}\text { Correlation with the } \\
\text { research objective }\end{array}$ & 7 & $\begin{array}{l}\text { Demonstrate how the research } \\
\text { questions addressed the research } \\
\text { objective by identifying the different } \\
\text { topics covered in the questionnaire. }\end{array}$ \\
\hline $\begin{array}{l}\text { Development of the } \\
\text { survey instrument }\end{array}$ & 8 & $\begin{array}{l}\text { Describe how the survey questionnaire } \\
\text { was developed, including reliability and } \\
\text { validity testing, pre-testing and pilot } \\
\text { testing. }\end{array}$ \\
\hline Sampling technique & 9 & $\begin{array}{l}\text { Unless the entire study population was } \\
\text { surveyed, identify how the sampling } \\
\text { was done, including any inclusion or } \\
\text { exclusion criteria (to establish the } \\
\text { representativeness of your sample) and } \\
\text { how the survey was sent (via email, } \\
\text { internet, etc.). }\end{array}$ \\
\hline Informed consent & 10 & $\begin{array}{l}\text { Describe how potential participants } \\
\text { were informed about who was } \\
\text { conducting the survey, its purpose } \\
\text { or objective, how long it would take } \\
\text { to complete, any incentives and } \\
\text { how personal information would be } \\
\text { protected. }\end{array}$ \\
\hline
\end{tabular}


Table 1: Checklist for reporting on surveys (continued)

\begin{tabular}{|c|c|c|}
\hline Reporting item & Item \# & Description \\
\hline \multicolumn{3}{|l|}{ Methods (continued) } \\
\hline $\begin{array}{l}\text { Optimization of } \\
\text { response rate }\end{array}$ & 11 & $\begin{array}{l}\text { Note what procedures were done } \\
\text { to optimize the response rate (e.g., } \\
\text { if an explanatory letter was sent } \\
\text { beforehand, or if reminders were sent } \\
\text { to non-responders). }\end{array}$ \\
\hline Measurement & 12 & $\begin{array}{l}\text { Describe all the measurements used } \\
\text { in the study, including characterization } \\
\text { of the study population, outcome } \\
\text { measures and the potential } \\
\text { confounding factors. }\end{array}$ \\
\hline Analysis & 13 & $\begin{array}{l}\text { Describe how the sample size was } \\
\text { calculated and any statistical analysis } \\
\text { that was undertaken. }\end{array}$ \\
\hline \multicolumn{3}{|l|}{ Results } \\
\hline $\begin{array}{l}\text { Response rate and } \\
\text { representativeness } \\
\text { of sample }\end{array}$ & 14 & $\begin{array}{l}\text { Present the number of responses, } \\
\text { the response rate and, if possible, } \\
\text { compare the characteristics of your } \\
\text { sample with what you know about the } \\
\text { study population (e.g., a physician } \\
\text { survey might include age, sex, years in } \\
\text { practice and location). }\end{array}$ \\
\hline $\begin{array}{l}\text { Presentation of } \\
\text { results }\end{array}$ & 15 & $\begin{array}{l}\text { Present the findings from the different } \\
\text { topic areas in the same sequence } \\
\text { that the topics were described in the } \\
\text { Methods. }\end{array}$ \\
\hline Tables and figures & 16 & $\begin{array}{l}\text { Have tables and figures that present } \\
\text { the key findings and ensure all } \\
\text { participants are accounted for. }\end{array}$ \\
\hline \multicolumn{3}{|l|}{ Discussion } \\
\hline $\begin{array}{l}\text { Summary of key } \\
\text { findings }\end{array}$ & 17 & $\begin{array}{l}\text { Summarize the main findings and } \\
\text { indicate how these address the } \\
\text { objective of the study. Highlight any } \\
\text { statistically significant results of clinical } \\
\text { or social relevance. }\end{array}$ \\
\hline $\begin{array}{l}\text { Comparative } \\
\text { analysis }\end{array}$ & 18 & $\begin{array}{l}\text { Explore how these findings were } \\
\text { consistent with or different from } \\
\text { other studies on a similar topic in the } \\
\text { literature. }\end{array}$ \\
\hline $\begin{array}{l}\text { Strengths and } \\
\text { limitations }\end{array}$ & 19 & $\begin{array}{l}\text { Identify the strengths and limitations } \\
\text { of your study. If the respondents were } \\
\text { not representative of the total sample, } \\
\text { or the sample was not representative } \\
\text { of the population of interest, consider } \\
\text { the implications of this. Consider if } \\
\text { and how potential bias has been } \\
\text { avoided or remains. }\end{array}$ \\
\hline Implications & 20 & $\begin{array}{l}\text { Consider the "so what?" of your } \\
\text { findings in terms of how it adds } \\
\text { to scientific knowledge, policy or } \\
\text { practice. }\end{array}$ \\
\hline Next steps & 21 & $\begin{array}{l}\text { Propose next steps or further areas for } \\
\text { inquiry without extrapolating too far } \\
\text { from your findings. }\end{array}$ \\
\hline Conclusion & 22 & $\begin{array}{l}\text { Ensure the conclusion integrates } \\
\text { the key findings and addresses the } \\
\text { objective of the survey. }\end{array}$ \\
\hline
\end{tabular}

\section{References}

1. Burns KE, Duffett M, Kho ME, Meade MO, Adhikari NK, Sinuff T, Cook DJ, for the ACCADEMY Group. A guide for the design and conduct of self-administered surveys of clinicians. CMAJ. 2008 Jul 29;179(3):245-52. DOI (http:// dx.doi.org/10.1503/cmaj.080372). PubMed (https://www. ncbi.nlm.nih.gov/entrez/query.fcgi?cmd=Retrieve\&db=PubM ed\&list_uids=18663204\&dopt=Abstract).

2. Marcano Belisario JS, Jamsek J, Huckvale K, O'Donoghue J, Morrison CP, Car J. Comparison of self-administered survey questionnaire responses collected using mobile apps versus other methods. Cochrane Database Syst Rev. 2015 Jul 27;7:MR000042. PubMed (https://www.ncbi.nlm. nih.gov/entrez/query.fcgi?cmd=Retrieve\&db=PubMed\&li st_uids $=26212714 \&$ dopt $=$ Abstract)

3. Eysenbach G. Improving the Quality of Web Surveys: The Checklist for Reporting Results of Internet E-Surveys (CHERRIES). J Med Internet Res. 2004 July-Sep; 6(3):e34. Correction J Med Internet Res 2012; 14(1):e8. DOI (http:// dx.doi.org/10.2196/jmir.6.3.e34).

4. Huston P. Reporting on surveys: information for authors and peer reviewers. CMAJ. 1996 Jun 1;154(11):1695704. PubMed (https://www.ncbi.nlm.nih.gov/ entrez/query.fcgi?cmd=Retrieve\&db=PubMed\&list_ uids=8646657\&dopt=Abstract).

5. Information for Authors: January 2017. Canada Communicable Disease Report. https://www.canada.ca/ en/public-health/services/reports-publications/canadacommunicable-disease-report-ccdr/submit-a-manuscriptinformation-authors.html 